\title{
Study of the physical quality of shallow ground water in Palu valley for drinking water
}

\author{
Saparuddin ${ }^{1 *}$ \\ ${ }^{1}$ Faculty of Engineering, Tadulako University, Palu, Central Sulawesi, Indonesia
}

\begin{abstract}
Water is a basic need in various human activities. drinking water for general purposes is generally supplied by the Regional Water Company (RWC), but RWC's ability to meet the needs of the community is felt to be limited. Potential groundwater around a large residential area and has been widely used for drinking water, this study aims to determine the physical quality of water and shallow groundwater classes in the Palu valley. By using laboratory analysis of shallow groundwater samples taken randomly in the existing Palu Valley where people use shallow ground water as a source of drinking water. The results of the study that the physical quality of shallow ground water in the Palu Valley meets the physical requirements of drinking water and includes class B water and can improve its physical quality into drinking water with simple processing.
\end{abstract}

\section{Introduction}

Water is a basic requirement for a range of human activities, In addition to fulfilling the daily needs such as drinking, cooking, washing, bathing, and sanitation, water is also needed in large quantities to meet the needs of economic and social activities.

Clean water for public purposes is generally supplied by the Regional Water Company (RWC), Need for clean water experience faster growth compared with population growth requiring more clean water, so that the percentage of the population served by the RWC is declining.

Potential ground water around the settlement is quite large and has been widely used by the community in a simple manner or using modern technology, either through individual effort or by means of together or group.

Clear groundwater is commonly found in mountainous areas and away from industrial areas, so that community can directly consume this crystal clear water, while groundwater in industrial areas and densely populated settlements are often polluted, ground water located in urban areas are generally still good, Contaminated groundwater is generally caused by human activities that do not care about the environment.

\footnotetext{
${ }^{*}$ Corresponding author: sapar_59@yahoo.co.id
} 
Palu valley constitute an alluvial deposit located on the coast of Palu Bay, located at an altitude between 0 to $200 \mathrm{~m}$ above sea level with temperatures between $21^{\circ} \mathrm{C}-30^{\circ} \mathrm{C}$, low rainfall less than $1000 \mathrm{~mm}$ per year, in contrast to other valleys that have a low temperature with high rainfall, now the capital of Central Sulawesi province with a relatively high population growth.

The advantages of using groundwater because of its relatively better quality compared to surface water and unaffected seasons, larger and more accessible groundwater reserves, and do not require large containers and transmission networks to distribute them [1].

\section{Research purposes}

\subsection{Groundwater}

The ground water is the water contained in the soil layer [2], the ground water is water that moves in the soil occupies the space between soil grains. Layers that are easily passed by ground water are called permeable layers, such as layers found in layers of sand or gravel, whereas a difficult layer of groundwater is called an impermeable layer, such as a clay or clay layer. Layers that can catch and pass water are called aquifers [3].

Ground water comes from rainwater and surface water, which permeates into the soil until it reaches the saturation zone and becomes groundwater [4], [5] Groundwater is a part of the water on Earth come from rainwater. Rainwater that falls on the soil surface and seeps into the soil then collects on a layer of soil that is impermeable. Groundwater follows the phase of the hydrological cycle, which is an event that always recurs from the sequence of stages through which water passes from the atmosphere to the earth and returns to the atmosphere, evaporation from land or sea and then again falls into rain.

From the hydrological cycle it can be understood that groundwater interacts with surface water and other components involved in the hydrological cycle including topographic forms, cover rock types, land use, cover plants, and humans residing in settlements. Groundwater and surface water are interrelated. Any pumping action, contamination of groundwater will react to surface water, and vice versa.

\subsection{Groundwater Quality}

The shallow ground water quality is highly determined by the surrounding soil conditions. If the surrounding soil is polluted, the water is polluted. Water in the process of infiltration and streaming, many substances that are dissolved or suspended therein. However, naturally water can cleanse itself during the process of infiltration and drainage [6].

Physical Quality Requirements Drinking Water is manifested in the form of turbidity, dissolved solids, smell, color, and taste as well as water temperature. Odor and taste difficult to distinguish, Generally the assessment of odors and flavors is often done simultaneously as an indicator, between the two is difficult to be separated quantitatively [7].

The flavor of water can be caused by the presence of dissolved gases such as H2S, living organisms, the presence of solid waste and liquid waste and the possibility of remnants of materials used for disinfectants such as chlorine. Pain on drinking water is pursued neutral or bargaining, so it can be accepted by drinking water consumers [8]. 


\section{Research Methods}

\subsection{Research sites}

The research location is situated in Palu valley bounded on the District that have a criterion as follows:

- $\quad$ Districts with a population density greater than 2,000 inhabitants / Km2.

- Districts whose communities use shallow ground water as a source of clean water for drinking water.

- $\quad$ District is flanked by Mount Gawalise on the west and hills on the East and not mediated by the Bay of Palu.

From the requirements set as the study location, the villages that meet the requirements for sampling are shown in table 1

Table 1. Village of sampling sites

\begin{tabular}{|c|c|c|c|c|}
\hline No & Districts & $\begin{array}{c}\text { Total of } \\
\text { villages }\end{array}$ & Size (Km2) & $\begin{array}{c}\text { Population } \\
\text { density }\end{array}$ \\
\hline 1 & West Palu & 6 & 8.28 & 7.042 \\
\hline 2 & East Palu & 5 & 7.71 & 8.74 \\
\hline 3 & South Palu & 5 & 27.38 & 2.342 \\
\hline 4 & Tatanga & 6 & 14.95 & 2.379 \\
\hline
\end{tabular}

\subsection{Population and Sample}

The population of this study is all shallow groundwater in the Palu Valley and utilized by the community as a source of drinking water, with a large sample of 3 points each village.

Assessment of shallow groundwater level based on existing water class in Palu Valley is done by qualitative and quantitative analysis, the result of each parameter examination is given value as Table 2 . Average water quality calculated with equation (1).

Table 2. The standard value according to the category of water quality

\begin{tabular}{|c|c|c|}
\hline Value & Quality & According to the water class \\
\hline 1 & Very good & Qualified water group (A) \\
\hline 2 & Good & Qualified clean water group (B) \\
\hline 3 & Poor good & Qualified raw water group (C). \\
\hline 4 & Not good & Meet the class of water group (D) \\
\hline
\end{tabular}

$$
\text { Average water quality }=\frac{\text { value sample result }}{\text { sample result }}
$$


The container used to take shallow ground water in the Palu Valley is the dug well in Fig. 1 or the suction pump in Fig. 2.

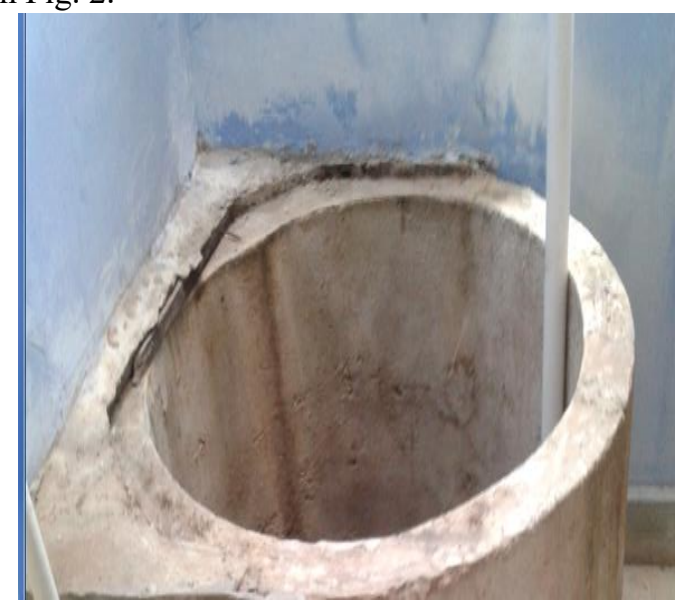

Fig. 1. Models of community wells

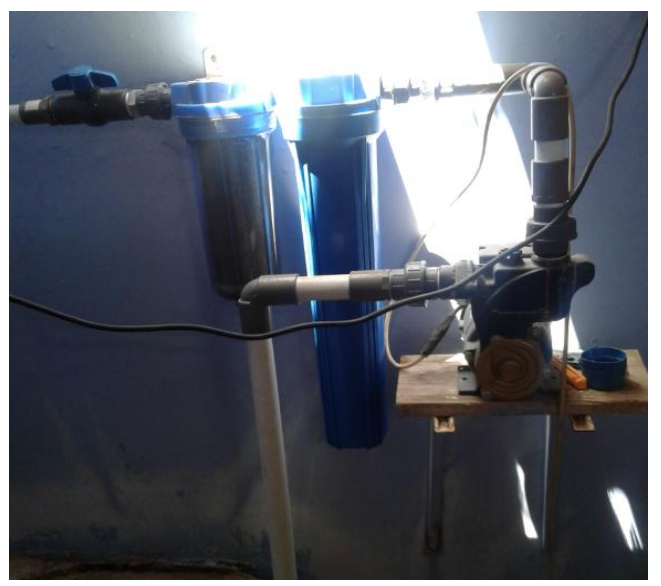

Fig. 2. Community Water Pump Model

\section{Results and Discussion}

Palu Valley as the capital of Central Sulawesi Province, the area of about $400 \mathrm{~km} 2$ is a plain with an altitude between 0 - 200 meters above sea level, flanked by mountains on the west side and hills on the east side. In the middle of the city there are several rivers flows into the Gulf of Palu.

\subsection{Research Results}

The physical properties of water can be analysed visually with the senses, for example cloudy or coloured can be directly seen, the smell can be with the nose, the taste with the tongue. The study is of course qualitative, for example if the smell is different with the taste of water is different or if the water is red then the smell that will smell is already predictable as well. This method can be used to analyse water simply because the physical properties of water 
are interrelated, while the turbidity parameters and dissolved solids were tested in laboratory using Turbidimeter with Nephelo Turbidity Unit scale (NTU)

\subsection{Analysis and Discussion}

Terms of water physics in this study focused on the value of turbidity of water. Turbidity describes the optical properties of water determined by the amount of light absorbed and emitted by the materials present in the water. The spread particles can be either organic substances are decomposed subtly, microorganisms, silt, clay and colloidal substances that are similar or floating objects that are in the water

Water that has a low turbidity value has the same color as the color of clear water. The high value of water turbidity is related to the amount of dissolved solids

\subsubsection{Analysis of water turbidity.}

Water turbidity can be caused by the presence of inorganic materials and organic watersoluble like material produced by industrial waste and other domestic activities. Examination of shallow ground water turbidity in Palu valley by using turbidimeter, of the 66 samples are presented in Table 3.

Table 3. Results of Checking Turbidity of water in Palu Valley NTU Scale

\begin{tabular}{|c|c|c|c|c|c|c|}
\hline Number & $\begin{array}{l}\text { Laboratory } \\
\text { results }\end{array}$ & Weight & $\begin{array}{l}\text { Sample } \\
\text { results }\end{array}$ & $\begin{array}{l}\text { Weight } x \\
\text { results }\end{array}$ & Percentage & Value \\
\hline 1 & 2 & 3 & 4 & $5=3 \times 4$ & 6 & $7=\Sigma 5 / \Sigma 4$ \\
\hline 1 & $<5 \mathrm{NTU}$ & 4 & 20 & 80 & 30.3 & \multirow{5}{*}{3.03} \\
\hline 2 & $5-15$ NTU & 3 & 31 & 93 & 46.97 & \\
\hline 3 & 16 - $25 \mathrm{NTU}$ & 2 & 12 & 24 & 18.18 & \\
\hline \multirow[t]{2}{*}{4} & $>25 \mathrm{NTU}$ & 1 & 3 & 3 & 4.55 & \\
\hline & & & 66 & 200 & 100 & \\
\hline
\end{tabular}

The data in Table 3 of the 66 samples of shallow ground water examined are $30.30 \%$ of which the turbidity of the water is less than 5 NTU meaning $30.30 \%$ of the turbidity of the water meets [9] which requires maximal turbidity $5 \mathrm{NTU}$, while the water turbidity between 5-15 NTU, as much as $46.97 \%$ means that this turbidity fulfills the water turbidity requirement for clean water [9] which requires a maximum water turbidity of $15 \mathrm{NTU}$, water turbidity data above $15 \mathrm{NTU}$ as much as $22.73 \%$ respectively as $18.18 \%$ turbidity between $16-25$ NTU and $4.55 \%$ of turbidity above 25 NTU.

Assessment of water turbidity quality based on the weight of the specified value is at 3.03, meaning shallow groundwater turbidity in the Palu Valley meets clean water quality standards and can be processed to be upgraded to drinking water through processing. 


\subsubsection{Dissolved Solids Analysis in Water}

Examination of soluble solids content of shallow groundwater in Palu valley consists of organic and inorganic elements, of the 66 samples in the laboratory test results obtained from the data, presented in Table 4.

Table 4. Results of Examination by Dissolved Solids mg / liter

\begin{tabular}{|c|c|c|c|c|c|c|}
\hline Number & $\begin{array}{c}\text { Laboratory } \\
\text { results (mg/l) }\end{array}$ & Weight & $\begin{array}{c}\text { Sample } \\
\text { results }\end{array}$ & $\begin{array}{c}\text { Weight x } \\
\text { results }\end{array}$ & Percentage & \multirow{2}{*}{ Value } \\
\hline 1 & 2 & 3 & 4 & $5=3 \times 4$ & 6 & \multirow{2}{*}{$7=\Sigma 5 / \Sigma 4$} \\
\hline 1 & $<500$ & 4 & 21 & 84 & 31.82 & \multirow{2}{*}{3.05} \\
\hline 2 & $500-1000$ & 3 & 29 & 87 & 43.94 & \\
\hline 3 & $1001-1500$ & 2 & 14 & 28 & 21.21 & \\
\hline 4 & $>1500$ & 1 & 2 & 2 & 3.03 & \\
\hline & & & 66 & 201 & 100 & \\
\hline
\end{tabular}

Data as shown in Table 4, of the 66 samples of shallow ground water examined contained $31.82 \%$ of the soluble solids content in water of less than $500 \mathrm{mg} /$ liter of water, meaning that the dissolved solids content in water meet drinking water standards in, which requires the dissolved solids content in drinking water maximum $500 \mathrm{mg} /$ lite of water, while the dissolved solids between $500-1000 \mathrm{mg} /$ liter of water, as much as $43.94 \%$ means that this soluble solid qualifies water for clean water which requires solids dissolved in clean water maximum 1,000 mg / liter of water. Data of dissolved solids that do not meet the requirements of clean water as much as $24.24 \%$ respectively as much as $21.21 \%$ of the dissolved solids between $1,000-1,500 \mathrm{mg} /$ liter water and $3.03 \%$ of the dissolved solids above $1,500 \mathrm{mg} /$ liter of water.

The shallow groundwater physical quality assessment of the soluble solid parameters based on the weight of the specified value is at 3.05, meaning that the shallow soluble solids water content in the Palu valley meets the clean water quality standards and can be processed to be upgraded to drinking water through processing.

\subsubsection{Water Color Analysis, TCU Scale.}

Color proofing shallow groundwater in Palu valley of the 66 samples tested in the laboratory are presented in Table 5.

Table 5. Water color inspection results

\begin{tabular}{|c|c|c|c|c|c|c|}
\hline Number & $\begin{array}{c}\text { Laboratory } \\
\text { results TCU }\end{array}$ & Weight & $\begin{array}{c}\text { Sample } \\
\text { results }\end{array}$ & $\begin{array}{c}\text { Weight x } \\
\text { results }\end{array}$ & Percentage & Value \\
\hline 1 & 2 & 3 & 4 & $5=3 \times 4$ & 6 & $7=\Sigma 5 / \Sigma 4$ \\
\hline 1 & $<15$ & 4 & 29 & 116 & 43.94 & \\
\hline
\end{tabular}




\begin{tabular}{|l|c|c|c|c|c|c|}
2 & $15-25$ & 3 & 17 & 51 & 25.76 & \multirow{3}{*}{3.09} \\
\hline 3 & $26-50$ & 2 & 17 & 34 & 25.76 & \\
\hline 4 & $>50$ & 1 & 3 & 3 & 4.55 & \\
\hline & & & 66 & 204 & 100 & \\
\hline
\end{tabular}

The data as shown in Table 5, of 66 samples of shallow ground water examined contain $43.94 \%$ of which the water color is less than $15 \mathrm{TCU}$, meaning shallow groundwater color in the Palu Valley meets drinking water [9] which requires the color of drinking water to be no more than $15 \mathrm{TCU}$, while the water color concentration between 15 to $25 \mathrm{CTU}$ of $25.76 \%$ means that the color of water is eligible for clean water[9] requires no more than $25 \mathrm{CTU}$ water color. The water color data that did not fulfill the water requirement of $30.31 \%$ were $25.76 \%$ of the color between 26 to $50 \mathrm{TCU}$ and $4.55 \%$, respectively, of which the color was more than 50 CTU.

The shallow groundwater physical quality assessment of the color parameters based on the specified value weights is at 3.09 , meaning that shallow ground water in the Palu Valley meets the clean water quality standards and can be processed to be upgraded to drinking water through processing.

\subsubsection{Odor Analysis.}

Result of examination of physical quality of shallow groundwater in Lembah Palu from 66 samples with odor parameter, in Table 6.

Data as in Table 6, of 66 samples of shallow groundwater examined contain $68.18 \%$ which does not indicate any odor to water, meaning shallow groundwater odor in Palu valley meets drinking water [9] which suggests drinking water should not smell, but from 66 samples examined still found there are $28.79 \%$ which is somewhat smelly and there are 2 samples or $3.03 \%$ smelly, this indicates that the presence of turbidity, dissolved solids and the colour of water that affect the smell water in the Palu Valley. While the sample is very odor is not obtained in research conducted.

The shallow physical groundwater quality assessment of the odor parameter based on the specified weight is at 3.65, meaning shallow groundwater odor in the Palu Valley meets the physical quality standards of clean water and can be processed to be upgraded to drinking water through processing such as by filtration.

Table 6. Water odor check results

\begin{tabular}{|c|c|c|c|c|c|c|}
\hline Number & $\begin{array}{l}\text { Laboratory } \\
\text { results }\end{array}$ & Weight & $\begin{array}{c}\text { Sample } \\
\text { results }\end{array}$ & $\begin{array}{l}\text { Weight } x \\
\text { results }\end{array}$ & Percentage & Value \\
\hline 1 & 2 & 3 & 4 & $5=3 \times 4$ & 6 & $7=\Sigma 5 / \Sigma 4$ \\
\hline 1 & Not smelling & 4 & 45 & 180 & 68.18 & \multirow{5}{*}{3.65} \\
\hline 2 & Rather smelling & 3 & 19 & 57 & 28.79 & \\
\hline 3 & Smelling & 2 & 2 & 4 & 3.03 & \\
\hline \multirow[t]{2}{*}{4} & Very smelling & 1 & 0 & 0 & 0 & \\
\hline & & & 66 & 241 & 100 & \\
\hline
\end{tabular}




\subsubsection{Flavor Analysis.}

It is known that drinking water condition that can be consumed by human is odorless and tasteless. Test on Pain is done to obtain a qualitative picture of the flavor intensity. The tool for testing the most suitable taste is the human tongue. The results of shallow physical groundwater quality testing of 66 samples with raasa parameter, are presented in Table 7.

Table 7. Water taste check results

\begin{tabular}{|c|c|c|c|c|c|c|}
\hline Number & $\begin{array}{l}\text { Laboratory } \\
\text { results }\end{array}$ & Weight & $\begin{array}{l}\text { Sample } \\
\text { results }\end{array}$ & $\begin{array}{c}\text { Weight } x \\
\text { results }\end{array}$ & Percentage & Value \\
\hline 1 & 2 & 3 & 4 & $5=3 \times 4$ & 6 & $7=\Sigma 5 / \Sigma 4$ \\
\hline 1 & Not Feeling & 4 & 49 & 196 & 74.24 & \multirow{5}{*}{3.71} \\
\hline 2 & Rather feeling & 3 & 15 & 45 & 22.73 & \\
\hline 3 & Taste & 2 & 2 & 4 & 3.03 & \\
\hline \multirow[t]{2}{*}{4} & Very taste & 1 & 0 & 0 & 0 & \\
\hline & & & 66 & 245 & 100 & \\
\hline
\end{tabular}

The results of the water taste test as shown in Table 7, of 66 samples of shallow ground water examined were $74.24 \%$ which did not show the taste of water, meaning that ground water flavor in Palu valley meets drinking water, which suggests drinking water should not be tasteless, but from 66 samples examined there are 22,73 which is somewhat tasteless, this indicates that the presence of elements contained in water, in the form of turbidity, dissolved solids and the color of water that affect the taste of water. While there are two samples or $3.03 \%$ of the 66 samples examined.

The shallow groundwater physical quality assessment of taste parameters based on the specified weight is at 3.71, meaning that shallow groundwater in Palu valley meets clean water quality standards and can be processed to be upgraded to drinking water through processing.

\subsubsection{Analysis of Water Temperature}

From 66 samples of ground water in Palu valley examined using thermometer, it is known that the water temperature is between $23^{\circ} \mathrm{C}$ to $30^{\circ} \mathrm{C}$ while the temperature around the sampling site is $21^{\circ} \mathrm{C} \mathrm{C}$ to $31^{\circ} \mathrm{C} \quad \mathrm{C}$. meets drinking water, requires a water temperature of about $\pm 3^{\circ} \mathrm{C}$ of ambient temperature, from the above data indicates that between the temperature around the sampling site with the temperature of the water samples examined does not show significant temperature difference, meaning that the water temperature qualifies as a source of drinking water.

\subsection{Discussion}

In this discussion, explained that the main object of research and its relationship with the purpose of research which has been conducted is known that the density of the settlements with the number of large population increases are also garbage into the soil which causes contamination of the water plant. 
The Palu Valley is a coastal area whose groundwater level is not far from the face of the land so that the community uses it as a source of drinking water

Physical examination results of 66 groundwater samples with water classification did not find low water quality parameters so that it can be categorized that ground water in the Palu Valley meets drinking water requirements.

The results of the analysis of the physical quality of shallow groundwater in Palu valley of the parameters examined is known that has a value, as in Table 8.

Table 8. Value of physical quality of water, research results

\begin{tabular}{|c|c|c|c|}
\hline Number & Parameters & Value Research & Description \\
\hline 1 & Turbidity & 3,03 & Clean water \\
\hline 2 & TDS & 3,05 & Clean water \\
\hline 3 & Color & 3,09 & Clean water \\
\hline 4 & Odor & 3,65 & Clean water \\
\hline 5 & Temperature & \pm 30 C Air temperature & Clean water \\
\hline 6 & Rasa Flavor & 3,71 & Clean water \\
\hline
\end{tabular}

\section{Conclusion}

The physical quality of shallow ground water in the Palu valley is included in class B and meets the requirements of clean water and can be upgraded to drinking water with simple processing.

\section{References}

1. Travis, C.C and Etnier, E.L, Groundwater Pollution, (1984).

2. Constitution of the Republic of Indonesia Number 7, About water resources, http://jdih.esdm.go.id/peraturan/UU-7-2004.pdf (2004)

3. Bejo, Understanding Groundwater, http://bejopoenya.blogspot.com/2009/06/ pengertian-air-tanah.html.(2009)

4. Sutandi M.C, Groundwater, http://repository.maranatha.edu/3914/1/Air\%20Tanah.pdf, (2012)

5. Rahadi B and Novia Lusiana N, Determination of Shallow Groundwater Quality http://Jtp.Ub.Ac.Id/Index.Php/Jtp/Article/Download/363/718,_(2012),

6. Frista Yorhanita, Zoning Potential of Water Pollution, https://media.neliti.com/media/publications/112640-ID-none.pdf, (2001)

7. Sony Saza, 2011, Understanding Groundwater, http://sonyaza.blogspot.com/pengertian- air-tanah.html (2011)

8. Darmono, Environment and Pollution. (2001)

9. Minister of Health of the Republic of Indonesia, Ministerial Regulation No. 492/Menkes/Per/IV/2010, (2010) 
10. Kusnadi, Processing Peat water and dirty Water. (2005).

11. 11. Handayani L, Design of Water Turbidity Measure Tool http://portal.fi.itb.ac.id/snips2015/files/snips_2015_linda_handayani_5bc2a1039bc5f29 dbe582460198f1fc9.pdf (2016) 